American Journal of Environmental Sciences 4 (4): 303-309, 2008

ISSN 1553-345X

(C) 2008 Science Publications

\title{
Evaluation, Selection and Assessment of Guidelines for Chemical Stabilization of Tropical Residual Soils
}

\author{
${ }^{1}$ Bujang B.K. Huat, ${ }^{2}$ Asmidar Alias and ${ }^{1}$ Azlan Abdul Aziz \\ ${ }^{1}$ Department of Civil Engineering, University Putra Malaysia Putra, Malaysia \\ ${ }^{2}$ Faculty of Civil Engineering, University Teknologi MARA, Pahang, Malaysia
}

\begin{abstract}
Soil stabilization has been widely used as an alternative to substitute the lacking of suitable materials on site. Guidelines and standards have been developed to assist practitioners in designing structures such as road by mean of stabilization. This paper presents the results of an investigation aimed at evaluating and assessing the suitable guidelines for the stabilization of tropical residual soils. Two types of tropical residual soils namely granite residual and sedimentary residual soil were tested by using conventional methods practiced in Malaysiaand two guidelines, namely the TRL and PWD were evaluated. From the results of this study, it appeared that the TRL gave a simplified and satisfactory route in selection of suitable binder for the stabilization processes of tropical residual soils.
\end{abstract}

Key words: Cement stabilization, compaction, granite residual soil, plasticity index, sedimentary residual soil, PWD, TRL, unconfined compressive strength

\section{INTRODUCTION}

Studies of soil stabilization by using solid stabilizing agents such as cement, lime and fly ash have been conducted on soils in many regions around the world. The uses of chemical additives have been used to improve the handling and engineering characteristic of soils for civil engineering purposes. Stabilized soils offer a viable alternative for road structural layers especially in resource scarce area. In Malaysia, the practice of using chemically stabilized soil is still uncommon, attributed to its high cost compare to the production cost of bituminous mix and concrete ${ }^{[3]}$. However, more than half of the area in Malaysia is covered with granite and sedimentary residual soils. Given the humid tropical climate that prevails in Malaysia which is characterized by high temperatures and heavy rainfalls, the formation of tropical residual soils is intense with a predominance of chemical weathering of rocks, thus resulting in deep weathering profiles and soil mantles often exceeding $30 \mathrm{~m}^{[4]}$. This feature gives relatively abundant materials for engineering works such as highway cut slopes, urban developments, dam site excavation, road constructions and others.

Based on surface geology, the soil distribution of Malaysia can broadly divided into three main types, granite residual soil, sedimentary residual soil and meta-sedimentary residual soil ${ }^{[4]}$. The residual soils are composite soils of sand, silt and clay in varying proportions depending on the geological setting of the soil $^{[5]}$. The granite residual soil and sedimentary residual soils are the two most commonly found type of residual soil in Malaysia.

As road construction benefited from the stabilization method, a number of guidelines based on soil stabilization have been developed throughout the globe. Most of the guidelines are equipped with comprehensive guide and mechanism in analyzing potential natural soils to be used in the soil stabilization process. However for case of Malaysia, the local guideline, $\mathrm{PWD}^{[2]}$ concerning soil stabilization is found to be simplified and inadequate.

This paper described a study that was done to determine the most appropriate guideline as basis of framework for further experimental works to assess the suitability of local residual soils stabilization. Suitable guideline for the local soils is important and would be systematic. The study builds upon the earlier preliminary work by reviewing local and regional researchers on soil stabilization for information on type of soil studied, their index properties, type and percentage of stabilizers used, their selection process and the performance of stabilized soil with regard to index properties, strength and durability. The study then focused upon increased in the load-bearing capacity as the basis of performance characterization as indicated by unconfined compressive strength (UCS). The specific objectives include determining required additive types and quantities, the magnitude of strength improvement and the relative strength improvement. 


\section{EVALUATION OF GUIDELINES}

A review of the literatures indicates that there has been local and regional researches done on the application of a number of binders including cement, lime, rice husk ash (RHA) as well as other chemical additive, such as Renolit for residual soil stabilization ${ }^{[6,7,8,9,10,11]}$. However it appears that none of these studies referred to any guideline in their binder selection process. The degree of improvement of in-situ soil may differ within a particular method and also between the methods.

A number of simplified guidelines for chemical stabilization of soils have been produced by several researchers. Most of the guidelines were made without specifying any restriction toward local condition or regional climates, which assumption can be made so that the guidelines can be used to suit any environment. Some of the guideline was purposely prepared to suit local environment. There is also guideline concerning the condition for similar climate for example tropical climate.

The only available local manual on method of chemical soil stabilization was developed by Public Works Department of Malaysia, PWD ${ }^{[2]}$. The guideline provides a minimal explanation to stabilize lateritic soil which it refers to as soil. The used of the term 'laterite' might itself bring some skepticism to the engineers, as not all residual soils harden on exposure to form laterite $^{[12]}$. The local engineers eventually correspond to the term of 'tropical residual soil' rather than the former used of laterites ${ }^{[13]}$. On the chemical soil stabilization process, the $\mathrm{PWD}^{[2]}$ recommends stabilization whenever CBR is less than $20 \%$ for natural (laterite) soil. However, the $\mathrm{PWD}^{[2]}$ stated that for cement stabilized soil, the stabilized soil must achieve CBR value of not less than $60 \%$. The strength achievement should be three time stronger than the natural soil. Two major aspects considered in $\mathrm{PWD}^{[2]}$ guideline are plasticity index and strength values, but the criteria are not explained explicitly for all conditions (i.e. sub grade, sub base or base). $\mathrm{PWD}^{[2]}$ stated that minimum strength to be achieved by cement stabilized for base course is $2.9 \mathrm{MPa}$. Furthermore, only Portland cement was suggested as the admixture to enhance the properties of soil. Examples of the criteria of soil stabilization proposed by $\mathrm{PWD}^{[2]}$ with regard to specific road structural layer are given by in Tables 1 and 2.

TRL $^{[1]}$ developed the Overseas Road Note 31 (ORN 31) as the result from various researches and development programs. TRL ${ }^{[1]}$ recommends the use of cement, lime and fly ash as chemical binder for soil stabilization for used in road base, sub-base, capping and selected fill layers of pavements. The selection of binder suggested by TRL ${ }^{[1]}$ mainly depends on the soil properties and plasticity index. Guide to select appropriate binder is shown in Table 3. The selection of binder strongly depends on the particle size distribution and the plasticity index, in two categories which are soil properties with more than $25 \%$ grain passing $0.075 \mathrm{~mm}$ (\#200 in ASTM standard) and less than 25\% passing the \#200 sieve. TRL ${ }^{[1]}$ specifies no limitation on soils PI but limits soil gradation for use as base construction material for likely maximum strength achievement.

Table 1: Standard properties of sub-base, $\mathrm{PWD}^{[2]}$

\begin{tabular}{|c|c|c|c|}
\hline Quality & Test method & Crushed aggregate & Sand, Laterite, etc. \\
\hline CBR (\%) & BS $1377^{[14]}$ & Not less than 30 & Not less than 20 \\
\hline Plasticity index (PI) & BS $1377^{[14]}$ & Not greater than 6 & Not greater than 6 \\
\hline Cement stabilized, CBR (\%) & BS $1377^{[14]}$ & - & Not less than 60 \\
\hline
\end{tabular}

Table 2: Material properties of base course, $\mathrm{PWD}^{[2]}$

\begin{tabular}{ll}
\hline Requirement & Cement stabilized \\
\hline Unconfined compressive strength (7 days) $\mathrm{Kg} \mathrm{cm}^{-2}$ & 30 to $40(2.9 \mathrm{MPa})$ \\
$\begin{array}{l}\text { Plasticity Index (PI) } \\
\text { gradation for base course }\end{array}$ & $\begin{array}{l}\text { Not greater than } 8 \text { nominal size of material } \\
\text { used shall not be greater than } 1 / 3 \text { of } \\
\text { compacted layer thickness }\end{array}$ \\
\hline
\end{tabular}

Table 3: Guide to the type of stabilization likely to be effective, TRL ${ }^{[1]}$

\begin{tabular}{|c|c|c|c|c|c|c|}
\hline \multirow[b]{3}{*}{ Type of stabilizer } & \multicolumn{6}{|c|}{ Soil properties } \\
\hline & \multicolumn{3}{|c|}{ More than $25 \%$ passing the $0.075 \mathrm{~mm}$ sieve } & \multicolumn{3}{|c|}{ Less than $25 \%$ passing the $0.075 \mathrm{~mm}$ sieve } \\
\hline & $\mathrm{PI}<10$ & $10<\mathrm{PI}<20$ & $\mathrm{PI}>20$ & $\mathrm{PI}<6 \mathrm{PP} * *<60$ & $\mathrm{PI}<10$ & $\mathrm{PI}>10$ \\
\hline Portland cement & Yes & Yes & $*$ & Yes & Yes & Yes \\
\hline Lime & $*$ & Yes & Yes & No & $*$ & Yes \\
\hline Lime- Pozzolan & Yes & $*$ & No & Yes & Yes & $*$ \\
\hline
\end{tabular}

*Marginally effective, $* *$ Plasticity product 
TRL $^{[1]}$ gives further guide for on method of preparing the samples, the curing processes which depend on types of binder selected and appropriate tests to be conducted.

TRL $^{[1]}$ specified the minimum acceptable strength of a stabilized material depending on its position in the pavement structure and level of traffic. The material should be strong enough to resist traffic stresses but upper limits of strength are usually set to minimise the risk of reflection cracking. Minimum strengths to be achieved base on the position of road structural layer are summarized in Table 4 . TRL ${ }^{[1]}$ suggested three types of stabilized layers strength requirement. $\mathrm{CB} 1$ is used in composite road base-unbound and cemented for traffic classes $6.0-30 \times 10^{6}$ ESA (equivalent standard axle). While CB2 and CS type of stabilized soil can be used for traffic classes as low as $0.3 \times 10^{6} \mathrm{ESA}$ for cemented road-base/surface dressing type of road construction.

Table 5 shows a summary of the above mentioned guidelines (TRL and PWD) highlighting the general information of the essential criteria and features of the guidelines. These guidelines insist on the importance of classifying the basic properties of soil, such as particle size distribution and plasticity index, for the selection of suitable binder. Of the two reviewed guidelines, only $\mathrm{TRL}^{[1]}$ states the procedure of determination the percentage of stabilizer content by trial and error, of 2 to $8 \%$ of the weight of dry soil.

\section{SELECTION OF GUIDELINES}

Based on the above, it appears that $\mathrm{TRL}^{[1]}$ would be the best available guideline to be adopted for the Malaysian tropical residual soils. In summary, this guideline is specially published to be adapted in tropical and semi-tropical climate region. Furthermore, the

extensive guide and procedure in selecting the suitable binder for a given properties of soil is provided. The existing local $\mathrm{PWD}^{[2]}$ guideline is too simplified and inadequate. Further experimental works were carried out in this study by incorporating the TRL ${ }^{[1]}$ method of soil stabilization.

Table 4: Properties of cement and lime-stabilized material, TRL ${ }^{[1]}$

\begin{tabular}{lll}
\hline Code & Description & $\begin{array}{l}\text { Unconfined compressive } \\
\text { strength (MPa) }\end{array}$ \\
\hline CB1 & Stabilized road-base & $3.0-6.0$ \\
CB2 & Stabilized road-base & $1.5-3.0$ \\
CS & Stabilized sub-base & $0.75-1.5$ \\
\hline
\end{tabular}

Table 5: Summary of reviewed guidelines

\begin{tabular}{|c|c|c|}
\hline Description & $\mathrm{TRL}^{[1]}$ & $\mathrm{PWD}^{[2]}$ \\
\hline Choice of stabilizers & Yes & No \\
\hline Stabilizers recommended & Cement Lime & Cement \\
\hline $\begin{array}{l}\text { Principal method of } \\
\text { stabilizers selection }\end{array}$ & $\begin{array}{l}\text { Particle size } \\
\text { distribution Plasticity } \\
\text { Plasticity index } \\
\text { Index Gradation } \\
\text { (for base material only) }\end{array}$ & \\
\hline $\begin{array}{l}\text { Suggestion of minimum } \\
\text { percentage of stabilizer }\end{array}$ & $\begin{array}{l}\text { Trial and error } \\
\text { (Starting with } 2 \text { to } 8 \% \text { ) }\end{array}$ & No \\
\hline Curing method & $\begin{array}{l}7 \text { days moist curing } \\
7 \text { days soaking }\end{array}$ & $\begin{array}{l}\text { Not } \\
\text { mentioned }\end{array}$ \\
\hline Experimental program & BS & BS \\
\hline Specific region & $\begin{array}{l}\text { Tropical and semi- } \\
\text { Tropical }\end{array}$ & $\begin{array}{l}\text { Local } \\
\text { (tropical) }\end{array}$ \\
\hline Construction method & Yes & No \\
\hline \multirow[t]{2}{*}{ Other contents } & $\begin{array}{l}\text { Description on } \\
\text { control of shrinkage } \\
\text { and reflection cracks }\end{array}$ & \\
\hline & $\begin{array}{l}\text { for road construction. } \\
\text { Explanation on } \\
\text { carbonation Quality } \\
\text { control Catalogue for road } \\
\text { construction design }\end{array}$ & None \\
\hline
\end{tabular}

Table 6: Summary of soil sample properties

\begin{tabular}{|c|c|c|c|c|c|c|}
\hline \multirow[b]{2}{*}{ Soil properties } & \multicolumn{3}{|c|}{ Granite residual soil } & \multicolumn{3}{|c|}{ Sedimentary residual soil } \\
\hline & $\mathrm{a}$ & $\mathrm{b}$ & $\mathrm{c}$ & $\mathrm{d}$ & $\mathrm{e}$ & $\mathrm{f}$ \\
\hline \multicolumn{7}{|l|}{ Textural composition (\%) } \\
\hline Gravel & 25 & 46 & 43 & 30 & 14 & 15 \\
\hline Sand & 61 & 45 & 50 & 67 & 77 & 78 \\
\hline Passing \#200 (0.075mm) & 14 & 9 & 7 & 3 & 9 & 7 \\
\hline \multicolumn{7}{|l|}{ Physical properties } \\
\hline Moisture content (\%) & 20.4 & 28.5 & 31 & 20.4 & 28.4 & 18.0 \\
\hline Specific gravity & 2.39 & 2.57 & 2.54 & 2.57 & 2.61 & 2.50 \\
\hline Liquid limit (\%) & 59.0 & 57.2 & 49.0 & 48.0 & 78.0 & 66.0 \\
\hline Plastic limit (\%) & 29.7 & 34.3 & 25.5 & 28.2 & 43.5 & 37.02 \\
\hline Plasticity index (\%) & 29.3 & 22.9 & 23.5 & 19.8 & 37.1 & 28.9 \\
\hline Linear shrinkage (\%) & 13.01 & 9.87 & 10.56 & 9.21 & 13.22 & 12.74 \\
\hline \multicolumn{7}{|l|}{ Soil classification } \\
\hline USCS & SW-SC & GW-GM & SW-SC & SW-SC & SW-SM & SP-SM \\
\hline Coefficient of uniformity, $\mathrm{Cu}$ & 27.08 & 22.00 & 22.22 & 11.67 & 7.50 & 6.83 \\
\hline Coefficient of curvature, $\mathrm{Cg}$ & 0.77 & 1.75 & 2.72 & 0.50 & 0.24 & 1.04 \\
\hline
\end{tabular}


Am. J. Environ. Sci., 4 (4): 303-309, 2008

Table 7: Selected binders based on guidelines

\begin{tabular}{llllll}
\hline & & & & Binder suggested \\
Soil origin & Soil sam-ple & Passing \#200 $(\%)$ & PI $(\%)$ & PWD $^{[2]}$ & TRL $^{[1]}$ \\
\hline Granit-ic soil & a & 14 & 29.3 & Cement & Cement Lime \\
& b & 9 & 22.9 & Cement & Cement Lime \\
\multirow{2}{*}{ Sedimentary soil } & c & 7 & 23.5 & Cement & Cement Lime \\
& d & 3 & 19.8 & Cement & Cement Lime \\
& e & 9 & 24.3 & Cement & Cement Lime \\
& f & 7 & 28.9 & Cement & Cement Lime \\
\hline
\end{tabular}

\section{EXPERIMENTAL WORK AND TEST MATERIALS}

The materials used in this study were granite and sedimentary residual soils, two of the most abundant type of residual soils found in Malaysia. The soil samples were collected from 6 different locations in the country. These samples were first partially dried under the sun and opened room until it was in a state that could be crumbled. Then the samples were dried in an oven before any further testing.

Basic tests such as particle size distribution (PSD) and Atterberg limits were first conducted to find the suitable chemical binder based on the guideline given by TRL ${ }^{[1]}$. The tests were conducted and performed in accordance to the British Standard ${ }^{[14]}$. The data of these index properties were used to classify the soil based on the Unified Soil Classification System (USCS). Summary of the soil samples properties are shown in Table 6.

The granitic residual soils consisted of gravel composition in the range of $25-46 \%$, sand of $45-61 \%$ and passing \#200, 7-14\%. The sedimentary residual soils exhibited gravel composition in the range of 14$30 \%$, sand of $67-78 \%$ and passing \#200 sieve size in the range of 3-9\%. All samples regardless of their origin showed coefficient of uniformity above 5 . The soils from granitic origin had coefficient of uniformity $(\mathrm{Cu})$ in the range of 22 to 27 , whilst soils of sedimentary rocks origin had $\mathrm{Cu}$ of 6 to 11. Only one soil sample appeared to have poor gradation while other soils were well-graded. According to TRL ${ }^{[1]}$, the grain distribution is not the most important factor if the main target is to achieve sub-base material strength. The gradation however is important when the soil is to be upgraded to base material. The soil of granite origin appeared to have larger gravel composition compared with soils of the sedimentary rock origin. All soils had more than $90 \%$ coarse grain size. The granite residual soils had PI in the range of $23-29 \%$, whilst the sedimentary residual soils had PI in the range of $19-37 \%$.
Selection of binder: Based on the experimental result on PSD and plasticity index (PI), the suitable binder is identified. Based on the results, cement and lime were found to be the suitable binders for the six selected soil samples as shown in Table 7. Cement however would have shorter curing time compared to lime. Under these circumstances, cement stabilization is likely to be more suitable than lime stabilization ${ }^{[1]}$. Ordinary Portland cement was finally selected as the chemical stabilizer.

Compaction tests: Compaction tests were carried out on 100-mm-diameter by 200-mm-high cylindrical specimens of each residual soil sample using compaction machine. This gave the required heightdiameter ratio for the UCS test of 2:1. The optimum moisture content and maximum dry density were determined by using British Standard (heavy) compaction $4.5 \mathrm{~kg}$ rammer ${ }^{[15]}$. The percentages of the amount of stabilizers added to the residual tropical soils were 6,8 and $12 \%$ by dry weight of the soil. The optimum water content measured from the modified proctor compaction was used as the target moisture content for each soil.

Unconfined Compression Test (UCS): Dry residual soil samples and the stabilizer were uniformly mixed together. For the unconfined compressive strength (UCS) test, the soil cement mixes were compacted at about $97 \%$ maximum dry density on the wet side of the Modified (heavy) Proctor corresponding to different percentage of stabilizer added to it. The resulting mixture was then compacted in the compaction mould. Specimens from the compaction mould were then extracted carefully and were placed in sealed bags. All samples were cured with at room temperature at three curing methods; 7 days moist cured, 14 days moist cured (for comparison purposes) and 7 days moist cured and 7 days soaking, following TRL ${ }^{[1]}$. Three specimens were prepared for each percentage of stabilizer and curing time respectively. The soil samples were then tested using a Multi-drive triaxial equipment, at a rate of $1.00 \mathrm{~mm} \mathrm{~min}$. The compressive strength was recorded in interval of $0.2 \mathrm{~mm}$ penetration. 
The minimum UCS values for structural road layers as stated in Table 4 actually correspond to the UCS value molded in $150 \mathrm{~mm}$ cube. However TRL ${ }^{[1]}$ provides correction factors for cases where the UCS were obtained from other mould sizes as shown in Table 8 . The TRL ${ }^{[1]}$ requires the soil to be cured at 7 days moist cure and 7 days soaking before being subjected to UCS test.

Table 8: Correction factors for equivalent cube strength, TRL ${ }^{[1]}$

\begin{tabular}{ll}
\hline Sample type & Correction factor \\
\hline $200 \mathrm{~mm} \times 100 \mathrm{~mm}$ diameter & 1.25 \\
$115.5 \mathrm{~mm} \times 105 \mathrm{~mm}$ diameter & 1.04 \\
$127 \mathrm{~mm} \times 152 \mathrm{~mm}$ diameter & 0.96 \\
\hline
\end{tabular}

Table 9: Summary of the UCS values

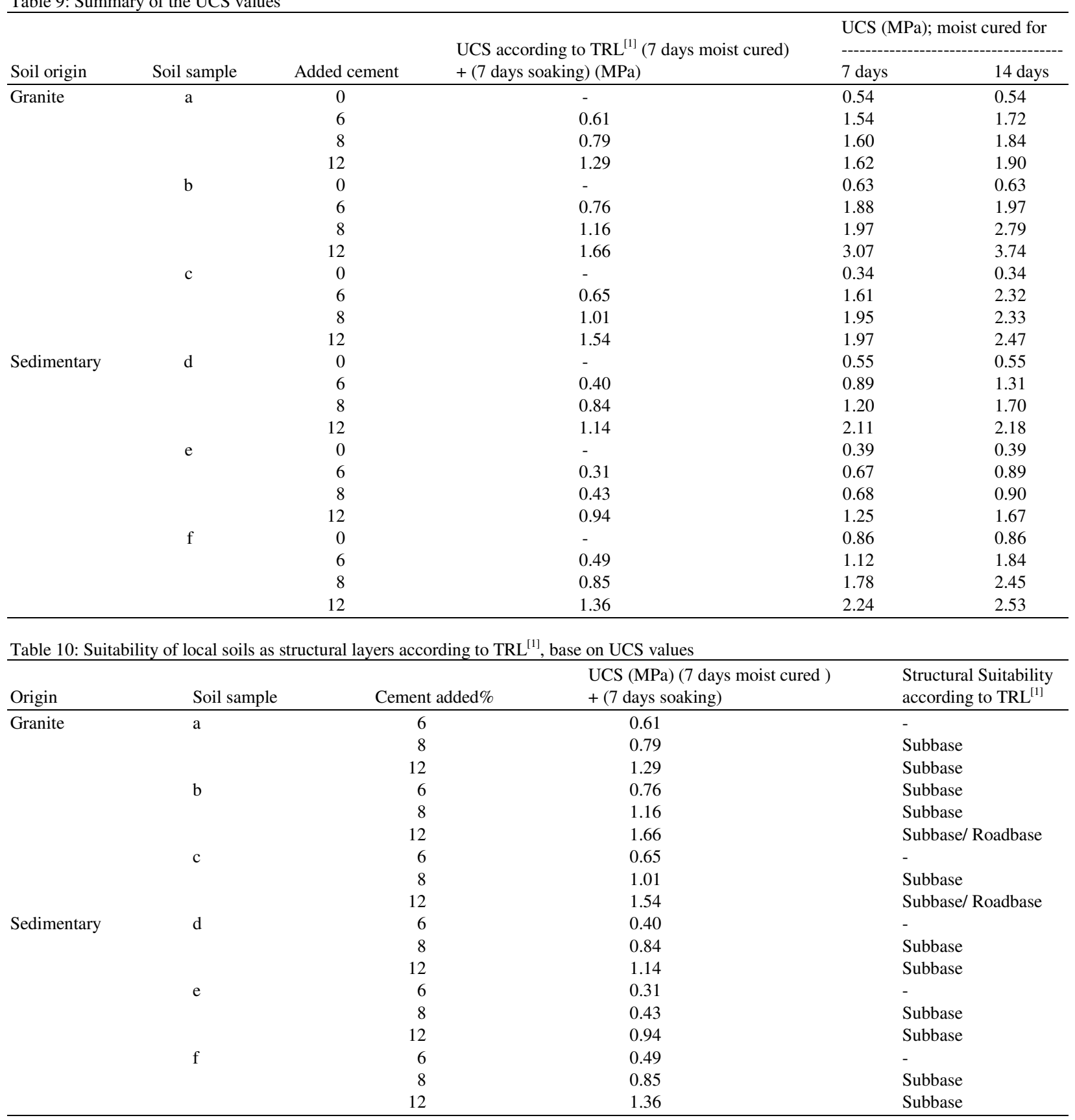




\section{RESULTS AND DISCUSSION}

Moisture density relationship: The results of modified proctor compaction test are presented in Fig. 1-2. The maximum dry densities (MDD) of both soils appeared to decrease marginally as more binders were added. Likewise then was a corresponding increase in the optimum moisture content (OMC). Although the curing was limited to about 2 hours, cement was known to have a fast reaction. The reduction of the soil maximum dry densities could be due to an immediate formation of cementitious products which reduced the compactibility and hence reduce the densities of the treated soil. Soil strength increment in stabilization process is not dependent on the compactive effort alone but also on the chemical reaction of the soil particle.

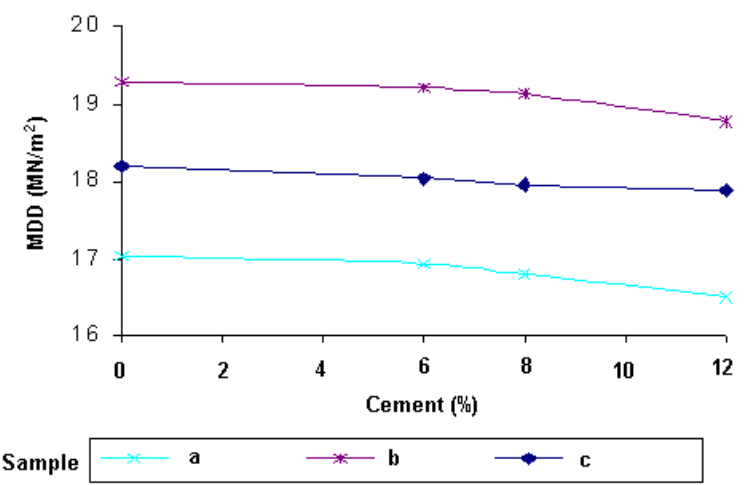

(a) Granite residual soils

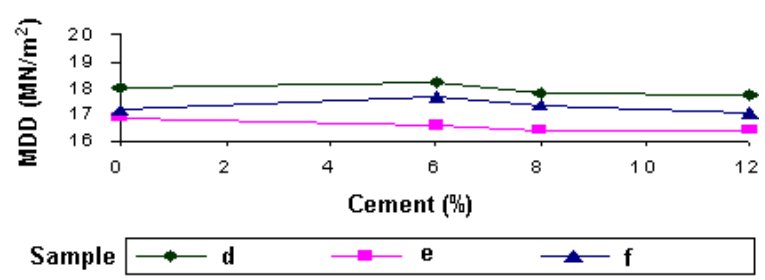

(b) Sedimentary residual soils

Fig. 1: Maximum dry densities (MDD) versus cement content

Unconfined compressive strength: In term of compressive strength, cement stabilizers yields prominent enhancement to the natural soil composite regardless of their origin of formation. The values of UCS shown in Table 9 were based on three methods of curing.

As seen from Table 9, strength gain for all the soil mixtures was more pronounce with more cement added into the soil mixture. The UCS values of all the cementstabilized soils are demonstrated as a function of cement content.

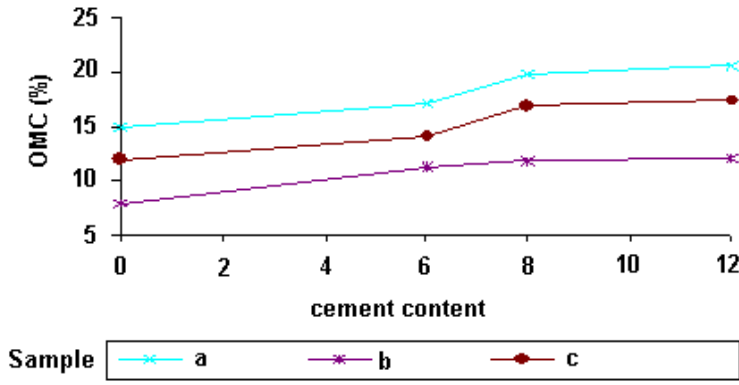

(a) Granite residual soils
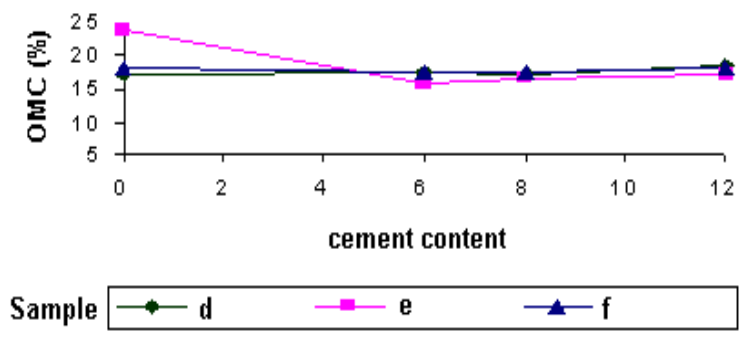

(b) Sedimentary residual soils

Fig. 2: Optimum moisture content (OMC) versus cement content

For granite residual soils (samples a, b, c), high strength gain was obtained when 6 to $12 \%$ cement was added to the soil mixture. Soils which had higher proportion of gravel, showed that the existence of coarse grains increased the soil load carrying capacity. In granular soils, cementing action is similar to concrete except that the cement paste does not fill the voids in the aggregate. However, it becomes cemented at the points of contact between the particles. Residual soils from sedimentary origin (samples Dear Sir, e, f) also exhibited the same behavior as the soil from granite origin.

Structural pavement layers: The TRL ${ }^{[1]}$ provides the minimum strength value for the soil mix for use as subgrade, subbase and base layer. Table 9 above shows a summary of the UCS values obtained for the local residual soils tested in this study. Table 10 shows the suitability of local soils as structural layers based on the UCS values, according to the guideline, TRL ${ }^{[1]}$. From Table 10 it could be seen all soil samples studied need at least $8 \%$ cement to qualify as sub-base. When added with $12 \%$ cement, some granitic residual soils with high gravel content and low PI can be made suitable as a road base of low volume roads. 


\section{CONCLUSION}

The main aim of this study was to review, evaluate and assess the suitability of the available guidelines for stabilizing tropical residual soils of Malaysia to enable them to be used as structural layers (sub-base and base) in road pavement. Two available guidelines, namely the $\mathrm{TRL}^{[1]}$ and $\mathrm{PWD}^{[2]}$ were examined with regard the prerequisite physical properties to select appropriate chemical stabilizers, the particle size distribution and gradation before soil stabilization process can be executed, curing methodand the minimum strength requirement for specified structural road layer (base or sub-base).

Based on the above, the TRL ${ }^{[1]}$ guideline appears to be most suitable for the residual soils of Malaysia.

The laboratory tests carried out on two most common types of residual soils, namely the granite residual soils and sedimentary residual soils showed that soils mixed with $8 \%$ cement appeared to exhibit a marked increase in strength to meet the requirement as sub-base material. With more cement added, there was further increase in the strength of the stabilized soils. In some cases, the strength gain with $12 \%$ cement was sufficient to meet the requirement as base material.

Soil with more coarse material, specifically gravel size material, tended to exhibit higher unconfined compressive strength (UCS) value. Soil plasticity index (PI) appeared to negate the positive effect of chemical stabilization.

\section{REFERENCES}

1. TRL, 1993. A guide to the design of bitumensurfaced roads in tropical and sub-tropical countries. Overseas road note 31 (ORN 31), 4th Ed., Transport Road Research Laboratory, Crowthorne, London, UK.

2. PWD, 1985. Manual on pavement design. Arahan Teknik (Jalan) 5/85. Public Works Department Malaysia. Kuala Lumpur.

3. Noor, M.J.M.L., 1994. Durability and strength characteristic of cement stabilized modified Melaka series. J. Islamic Acad. of Sci., Vol. 1.
4. Tan, B.K., 2004. Country case study: engineering geology of tropical residual soils in Malaysia. In Huat et al. (Ed.). Tropical Residual Soils Engineering. Balkema, Netherlands, 14: 232-244.

5. Balasubramaniam, A.S., D.T. Bergado and C. Sivandran, 1985. Engineering behavior of soil in Southeast Asia. In Balasubramaniam et al. (Ed.) Geotechnical Engineering in Southeast Asia. A commemorative volume of the Southeast Asian Geotechnical Society.

6. Ali, F.H., 1990. Improvement of a residual soil. Proceedings of the 10th Southeast Asian Geotechnical Conference, Taipei, Republic of China, 16: 1-8.

7. Ali, F.H., A. Aminuddin and K.C. Chew, 1992. Use of rice husk ash to enhance lime treatment of soil. Canadian Geotechnical J., 29: 843-852.

8. Lee, S.T. and F.H. Ali, 2004. Behaviour of clayey soils with cement additive. Proceedings of the Malaysia Geotechnical Conference. The Institution of Engineers Malaysia. Subang, Malaysia.

9. Wong, K.H., 2003. Assesment of an acrylic polymer on the properties of soil-cement. MSc. Thesis, University Putra Malaysia, Serdang, Selangor.

10. Mohamed, A.M.O. and K.I. Hosani, 2000. Effects of added lime on the soil engineering properties. Geoengineering in Arid Lands, Balkema, Rotterdam.

11. Siswosoebrotho, B.I., M. Hossain, A. Alias and B.B.K. Huat, 2004. Stabilization of tropical residual soils. In Huat et al. (Ed.). Trop. Residual Soils Eng., Balkema, Netherlands, 9 :145-168.

12. Northmore, K.J., M.G. Culshaw and P.R.N. Hobbs, 1992. Engineering geology of tropical red clay soils. Project background, study area and sampling sites. British Geological Survey, Keyworth, Nottingham.

13. IKRAM, 1996. Geoguides 1-5, Tropical weathered in-situ materials. Public Works Institute Malaysia.

14. BSI, 1990. Methods of test for soils for civil engineering purposes. British Standard Institution, London. 